\title{
Trabalho, Cidadania e Reconhecimento
}

\begin{abstract}
Sílvio Camargo*
SILVA, Josué Pereira. Trabalho, Cidadania e Reconhecimento. São Paulo: Annablume: 2008, 165 p.

Neste livro o professor de teoria sociológica da Unicamp Josué Pereira da Silva - apresenta um panorama do seu trabalho em mais de uma década, abordando alguns dos temas cruciais presentes nos debates da teoria social contemporânea, constituindo-se, ao mesmo tempo, como uma reflexão original quanto a alguns dos problemas mais debatidos acerca da modernidade tardia. Em um livro composto de seis capítulos e um epílogo o autor apresenta um nexo coerente de seu próprio amadurecimento teórico que acaba por mostrar uma articulação convincente entre trabalho, cidadania e reconhecimento, ao longo de um texto que apesar da densidade teórica é de uma leitura agradável.

O livro abre com um capítulo em torno do debate acerca da sociedade do trabalho, demarcando um dos pontos de partida teóricos do autor que é sua confluência para o entendimento de que o trabalho assalariado nos marcos da sociedade industrial já não mais corresponde à realidade do capitalismo contemporâneo. Transitando pela vasta literatura em sociologia do trabalho que nas duas últimas décadas tem se debruçado sobre o tema do esgotamento da sociedade do trabalho o texto traz com fluidez reflexões de Offe, Habermas e Gorz (de cuja obra o autor é um dos principais especialistas em língua portuguesa) sem se constituir, entretanto, como uma resenha destes autores. Inspirado fortemente pela obra de André Gorz e o impacto que desde a década de 1980 teve a publicação de Adeus ao Proletariado, Josué P. da Silva assume uma
\end{abstract}

Professor no Departamento de Sociologia, IFCH, Campinas/SP, Unicamp. Endereço eletrônico: silviocc@terra.com.br. 


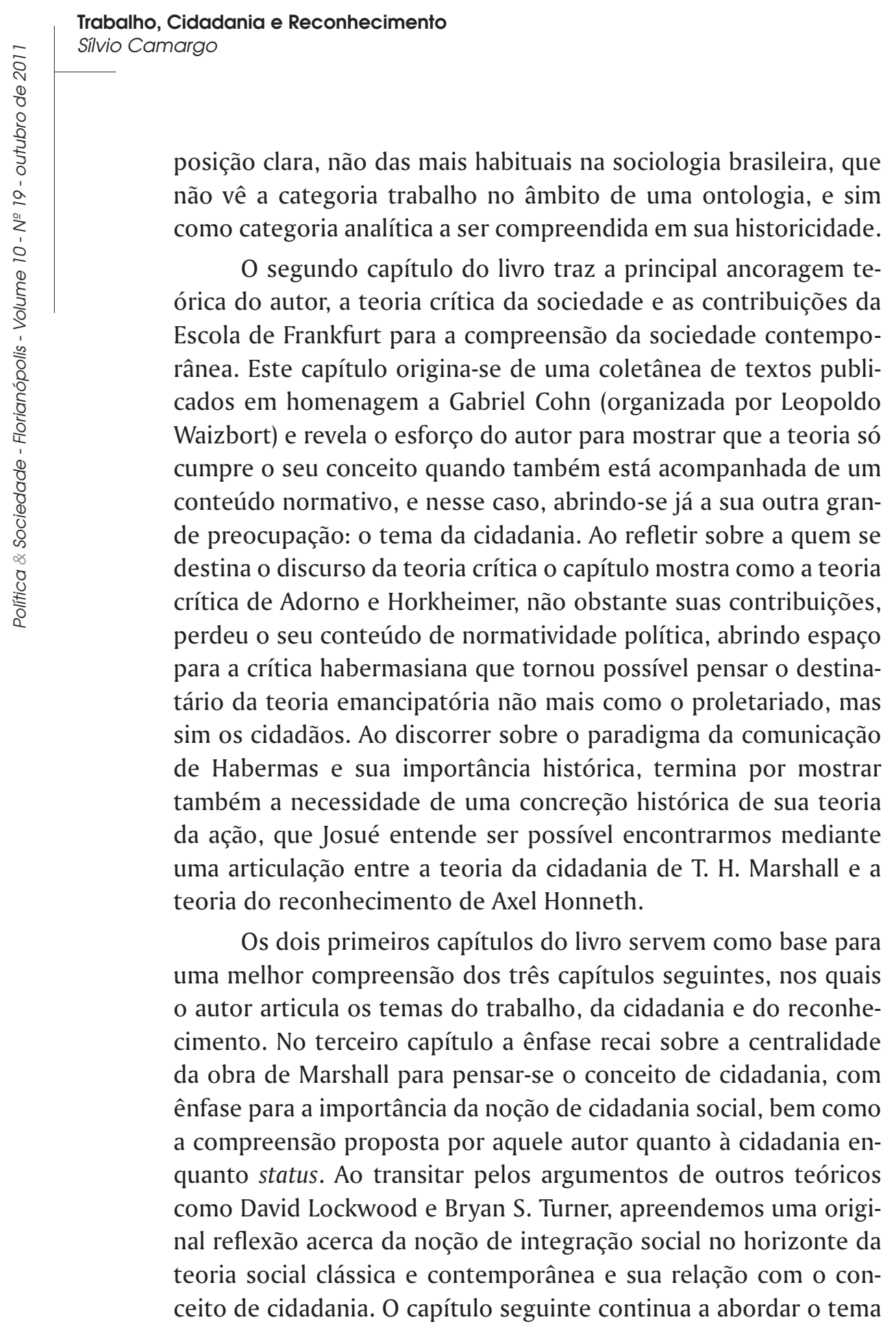


da cidadania, mas agora o articulando claramente com as ideias presentes no início do livro quanto ao esgotamento do paradigma da produção. Como pensar a cidadania social, que inclui o trabalho, em uma sociedade em que este se esgotou nos moldes modernos? Assim surge a reflexão sobre o papel histórico cumprido pelo Welfare State, e a retomada do pensamento mais recente de Gorz, autor que procura oferecer parâmetros normativos quanto à possibilidade de uma cidadania que não tenha mais no trabalho assalariado o seu fundamento social.

No capítulo seguinte percebemos a aproximação do autor com a teoria do reconhecimento de Honneth, vislumbrando nesta uma possibilidade de superação da normatividade abstrata de Habermas e a recuperação das intenções originais da teoria crítica. Ao mesmo tempo em que reconstrói os argumentos centrais de Honneth, apresenta o debate contemporâneo entre reconhecimento e redistribuição que tem Nancy Fraser como outra grande expoente. Aqui os temas do trabalho e da cidadania reaparecem como passíveis de também serem compreendidos à luz de uma teoria crítica do reconhecimento.

Os temas do trabalho, da cidadania e do reconhecimento reaparecem no último capítulo em uma tentativa do autor de pensá-los no contexto brasileiro, porém relacionando-os ao tema da desigualdade. Após apresentar um breve esboço do debate sobre a desigualdade na sociologia brasileira o pesquisador traz à tona a problematização entre cidadania e trabalho em sua relação com os projetos recentes, como do Senador Suplicy, de estabelecimento de uma renda básica como forma garantidora de uma cidadania que não esteja mais vinculada ao modelo do trabalho assalariado. O autor faz assim uma crítica de posições correntes sobre o tema, inclusive a de Suplicy, bem como de alguns projetos implementados no Brasil recentemente, destacando seus méritos e limitações.

O livro de Josué Pereira da Silva reúne assim um conjunto de textos que possuem uma evidente coerência lógica no encadeamento dos problemas - teóricos e históricos - que mobilizam o autor, manifestando uma notável erudição da literatura socioló- 
Trabalho, Cidadania e Reconhecimento

Silvio Camargo

5
2
0
0
0
0
3
5
0
1
0
01
1
1
0
8
5
0
1
5
0
2
0
0
0
4
1
0
0
0
0
0
0
0
0
0
0
0

gica e, principalmente, evidenciando que é possível defender um modelo, o da teoria crítica, em um diálogo permanente com outras vertentes da teoria social, como aquelas que abordam o tema da justiça, num momento histórico em que cabe também à teoria proposições político-normativas frente a um quadro social ainda inalterado de desigualdades e injustiça social.

Recebido em: 01.03.2010

Aprovado em: 17.01.2011 